\begin{tabular}{|c|c|}
\hline \multirow{3}{*}{ 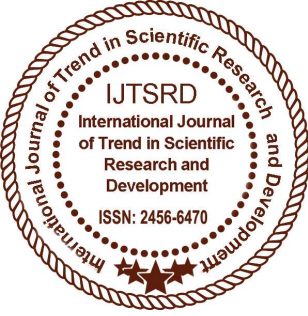 } & $\begin{array}{l}\text { International Journal of Trend in Scientific } \\
\text { Research and Development (IJTSRD) }\end{array}$ \\
\hline & International Open Access Journal \\
\hline & ISSN No: 2456 - 6470 | www.ijtsrd.com | Volume - 2 | Issue - 4 \\
\hline
\end{tabular}

\title{
Seasonal Dynamics of Arbuscular Mycorrhizal Fungi, Glomalin and Soil Properties in Agroecosystems of Nanded District
}

\author{
Ujwala Sheshrao Deepake ${ }^{1}$, Somesh Atmaram Sawale ${ }^{2}$ \\ ${ }^{1}$ Researcher, School of Life Sciences, Swami Ramanand Teerth Marathwada University, \\ Nanded, Maharashtra, India \\ ${ }^{2}$ Researcher, Department of Veterinary Medicine, Veterinary College Hebbal, \\ Banglore, Karnataka, India
}

\section{ABSTRACT}

To understand the ecological significance of arbuscular mycorrhizal fungal (AMF) associations in agroecosysytem, the host specific and seasonal dynamics of AMF and glomalin-related soil protein (GRSP) was investigated in agricultural fields of Nanded, Maharashtra State. Soil samples were collected from the rhizosphere of eight crop plants (Glycine max (L.) Merr., Saccharum officinarum L., Zea mays L., Cajanas cajan (L.) Millsp., Gossypium arboreum L., Triticum aestivum L., Sorghum vulgare Pers. and Cicer arietinum L.) in winter, summer and monsoon seasons respectively. Arbuscular mycorrhizal root infection and spore density of AMF peaked in monsoon and winter. The mean contents of total glomalin related soil proteins (T-GRSP) reached maximal values in summer. Spore density was highest in Zea mays L. Easily extractable glomalin related (EE-GRSP) and T-GRSP fractions were the highest in the rhizosphere of Cicer arietinum L. and Sorghum vulgare Pers. AMF root colonization and spore density was negatively correlated with $\mathrm{K}(\mathrm{P}<0.05$; $\mathrm{P}$ $<0.01)$. T-GRSP fraction was positively correlated with edaphic factors (rhizosphere temperature, $\mathrm{K}$ and Fe content of soil) and negatively correlated with soil moisture $(\mathrm{P}<0.01)$, AMF root colonization $(\mathrm{P}<0.05)$ and spore density $(\mathrm{P}<0.01)$.

Therefore, it can be inferred that the response of AMF varies with different crop plants and hence it reflects the variations in glomalin, and suggest that glomalin is produced in environmental stress on the basis of its relationship with soil physicochemical parameters, and can be implicated for evaluating soil quality in agricultural fields.

Keywords: Glomalin; AMF; edaphic factors; crop plants; seasonal variations

\section{INTRODUCTION}

Arbuscular mycorrhizal fungi (AMF) are mutualistic symbionts living in association with the roots of the majority of land plants. These are key determinants of the soil/plant system influencing soil fertility and plant nutrition (Smith and Read, 2008). The large network of fungal hyphae which spreads from mycorrhizal roots into the surrounding soil affects the physico-chemical characteristics of soils and represents stabilizing agents in the formation and maintenance of soil structure (Miller and Jastrow, 2000). AMF contribute to soil aggregation through the hyphal entanglement process assisting in soil aggregate formation (Jastrow and Miller, 1997). AMF produce glomalin, an extracellular glycoprotein that can adhere to inorganic materials and helps to stabilize soil aggregates (Wright et al., 1996, Wright and Upadhyaya, 1998; Rillig et al., 2001).

The broad or narrow association of AMF with distinct plant species in natural environments provide crucial information in the understanding of the ecological role of AMF on plant co-existence. Influence of AMF on agro-ecosystems and crop plants have been observed and acknowledged by many researchers (Graham 2001, Hodge et al., 2001, Davies et al., 
2002; Auge et al., 2004; Al-Karaki et al., 2001). It was also reported that changes in edaphic factors can substantially influence AMF association and spore numbers (Abbott and Robson, 1991). In addition numerous studies have examined seasonality of AMF spore production and root colonization (e.g., Anderson et al., 1984; Gay et al., 1982; Johnson et al., 1991; Mullen and Schmidt, 1993; Sanders and Fitter, 1992). However, studies examining the seasonality of GRSP in agroecosystem are sparse. Therefore, it is important to explain how seasonal changes, plant species and their mycorrhizal status are related to varying glomalin concentrations in agro-ecosystem.

Nanded is one of the fertile districts of Maharashtra state, India. It has more importance in the agricultural sector due to high fertile area. The majority of land area is cultivated for jowar, cotton, wheat, sugarcane, rice, maize and other pulses (Shahapurkar and Gajre, 2011). There is lack of information on the glomalin and AMF in agricultural fields of Nanded. The objectives of the present study were to evaluate seasonal changes in AMF and glomalin concentration in the rhizosphere of Glycine $\max$ (L.) Merr., Saccharum officinarum L., Zea mays L., Cajanas cajan (L.) Millsp., Gossypium arboreum L., Triticum aestivum L., Sorghum vulgare Pers. and Cicer arietinum L. in Nanded and to examine the relation of AMF root colonization, spore density and glomalin with soil physicochemical parameters.

\section{MATERIALS AND METHODS}

\section{A. Study Site}

The present study sites situated in Nanded district, Maharashtra, India and experiences three major seasons namely summer, monsoon and winter. All the sampling sites are agricultural lands of conventional farming types. Geographically Nanded district is lying between $18^{\circ} 15^{\prime}$ to $19^{\circ} 55^{\prime}$ North latitudes and $77^{\circ} 7^{\prime}$ to $78^{\circ} 10^{\prime}$ East longitudes. The total geographical area of the district is $10,760 \mathrm{sq} . \mathrm{km}$ that is $3.41 \%$ of the total area of the state. The district has 16 talukas. The average rainfall in the district is about $897.8 \mathrm{~mm}$ (35.34 inches). Physiographically the district is divided into three broad divisions, viz. hilly region, plateau region and plain region. This region has black, lateritic and alluvial soils. Godavari is the main river of the study region which flows west to east in the central part of the district. The climate in the district is hot and dry except the monsoon season. The nearest agricultural fields in some regions (Ardhapur, Loha and Kandhar) of district (Fig.1) were surveyed for crop plants. The major crop plants grown in these regions include Glycine max (L.) Merr., Saccharum officinarum L., Zea mays L., Cajanas cajan (L.) Millsp., Gossypium arboreum L., Triticum

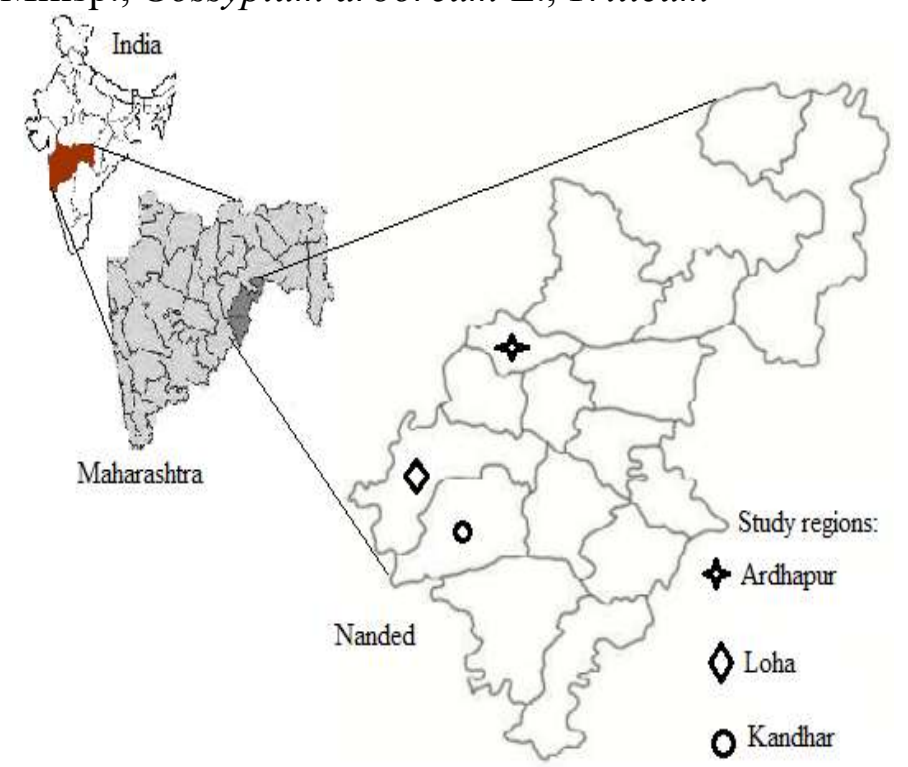

Figure 1: Geographical locality of the study sites.

aestivum L., Sorghum vulgare Pers. and Cicer arietinum L. Therefore, these crop plants were selected for the present study.

\section{B. Sample Collection}

The rhizospheric soil samples and fresh roots were collected from agricultural crop plants (G. max, $S$. officinarum, Z. mays, C. cajan, G. arboreum, $T$. aestivum, $S$. vulgare, and $C$. arietinum) during three seasons from agricultural fields. The soil samples were collected from 10 to $30 \mathrm{~cm}$ depth. The temperature was recorded at the site of collection. All the samples were transported to the laboratory in polythene bags and store at $4{ }^{\circ} \mathrm{C}$ until analysis (Sieverding, 1991).

\section{Soil Analyses}

Soil $\mathrm{pH}$ was determined with a digital $\mathrm{pH}$ meter (DPH 500, Superfit Continental) on (1:2, soil:water) suspension. Moisture content of soil was estimated (Trivedy et al., 1998). Total carbon and organic matter was determined by the Walkley \& Black method (Anderson and Ingran, 1989). The level of mineralizable $\mathrm{N}$ was measured by Kjeldahl method (Subbiah and Asija, 1956). Available phosphorus $(\mathrm{mg} / 100 \mathrm{gm}))$ in soil was determined as per the method of Ball-Coelho et al. (1993). Aqua-regia $\left(\mathrm{HNO}_{3}: \mathrm{HCl}=1: 3\right)$ was used for the extraction of $\mathrm{K}$ 
and $\mathrm{Fe}$ and measured by atomic absorption spectrophotometer (Perkin Elmer AAnalyst 100).

\section{Estimation of AM Fungal Infection}

The collected root samples were properly washed in running tap water and cleared in a near-boiling $10 \%$ aqueous solution of $\mathrm{KOH}$ for $48 \mathrm{hrs}$. Roots were stained in lactophenol cotton blue following several washings in distilled water to drain out the $\mathrm{KOH}$ (Phillips and Hayman, 1970). The stained roots were cut into $1 \mathrm{~cm}$ segments, and 80-100 such segments were picked up and examined under the microscope (Olympus CH 20i). AM colonization was expressed as the percent of infected root segments (Nicolson, 1955).

\section{E. Extraction and Enumeration of AM Fungal Spores}

Extraction of AM fungal spores from soil was done as described by Gerdmann and Nicolson, (1963). $50 \mathrm{~g}$ of soil was dispersed in $500 \mathrm{ml}$ water and decanted through a series of sieves (from $710 \mu \mathrm{m}$ to $38 \mu \mathrm{m}$ ). Residues were filtered through gridded filter papers and all intact spores (non-collapsed spores with cytoplasmic contents, free from parasitic attack) were counted under a stereomicroscope (SZ-790, Labomed) at 40x magnification. A sporocarp and spore clusters were considered as one unit. AM spore density was determined as the number per $50 \mathrm{~g}$ of dry soil.

\section{F. Extraction and Estimation of Glomalin}

Soil samples were ground to a fine powder before analysis. Glomalin extractions were conducted as described by Wright and Updahyaya (1996). Two fractions of glomalin related soil protein (GRSP) were analysed. Easily extractable glomalin related soil protein (EE-GRSP) was extracted at $121{ }^{\circ} \mathrm{C}$ for 30 min in $20 \mathrm{mM}$ citrate $(\mathrm{pH} \mathrm{7})$ and total glomalin related soil protein (T-GRSP) was extracted at $121{ }^{\circ} \mathrm{C}$ in $50 \mathrm{mM}$ citrate $(\mathrm{pH} 8)$ in 1-hour increments until the supernatant was almost colourless. The concentrations (mg per $\mathrm{g}$ of dry soil) of GRSP fractions were measured by Bradford assay using bovine serum albumin as a standard.

\section{G. Statistical Analyses}

The data was analysed by one-way analysis of variance (ANOVA) and differences among means for three different seasons were assessed by Tukey test ( $P$ $<0.05)$. Pearson's correlation analysis was employed to check the relationship between soil edaphic factors, root colonisation by AMF, AMF spore density and
GRSP at 0.01 and 0.05 levels of probability. The significant relationships obtained from this analysis were inferred by linear regression model with the software package SPSS 13.0 for Windows. Further, principal component analysis (PCA) was carried out for the construction of a mathematical model explaining the correlations between the sets of variables for three different seasons. The number of components with eigenvalue greater than one was extracted and plotted with PCA diagram. R program was used for PCA analysis.

\section{Results}

\section{A. Soil Properties}

The mean values of soil physicochemical characteristics are presented in Fig. 2, which varies significantly in all three seasons. The soil analyses revealed that rhizospheric soil temperature ranged between 15 and $35^{\circ} \mathrm{C}$. It was found to be high in summer and significant differences were found among the seasons $(P<0.05) . \mathrm{pH}$ was observed in alkaline range from 7.58 to 8.54 and no significant differences were observed among seasons except $G$.
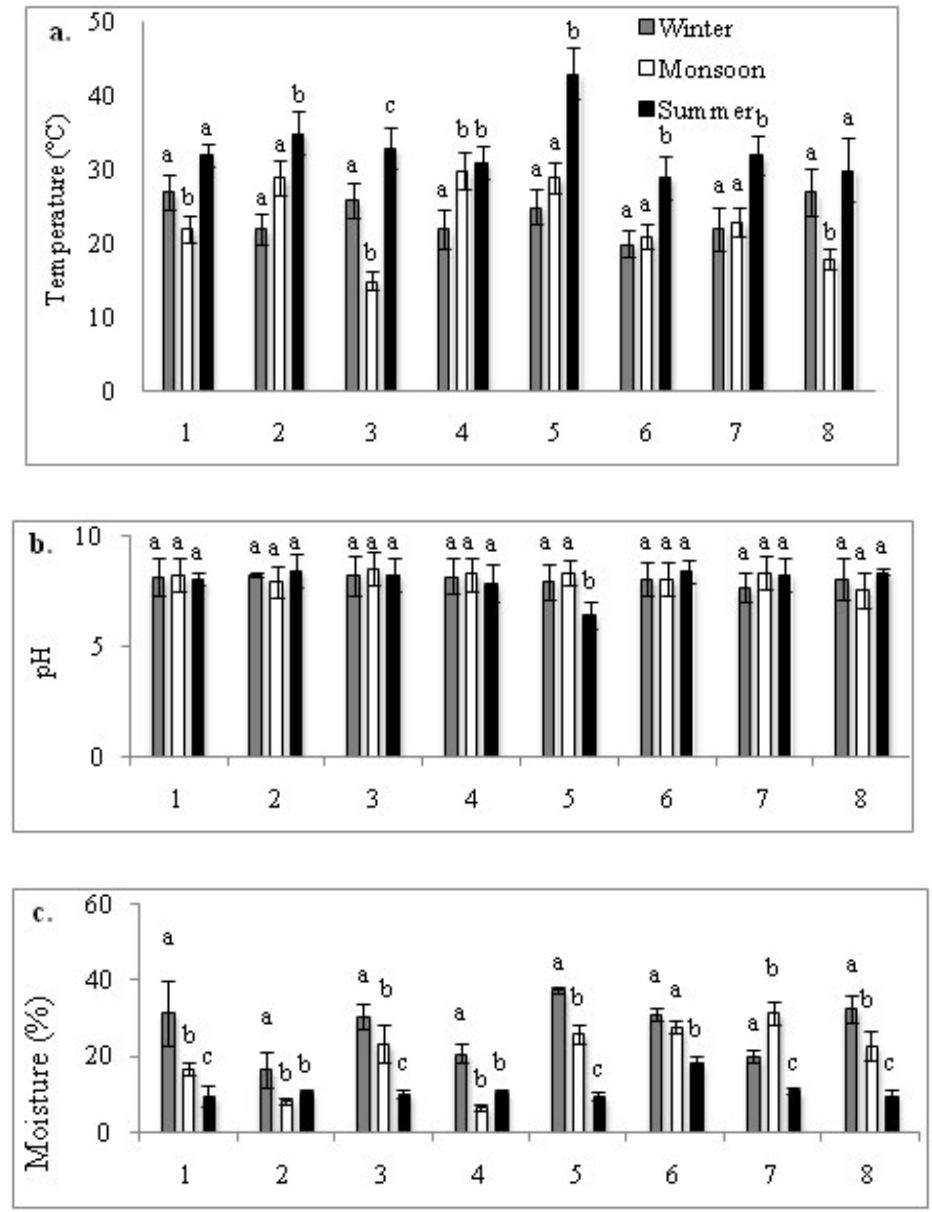

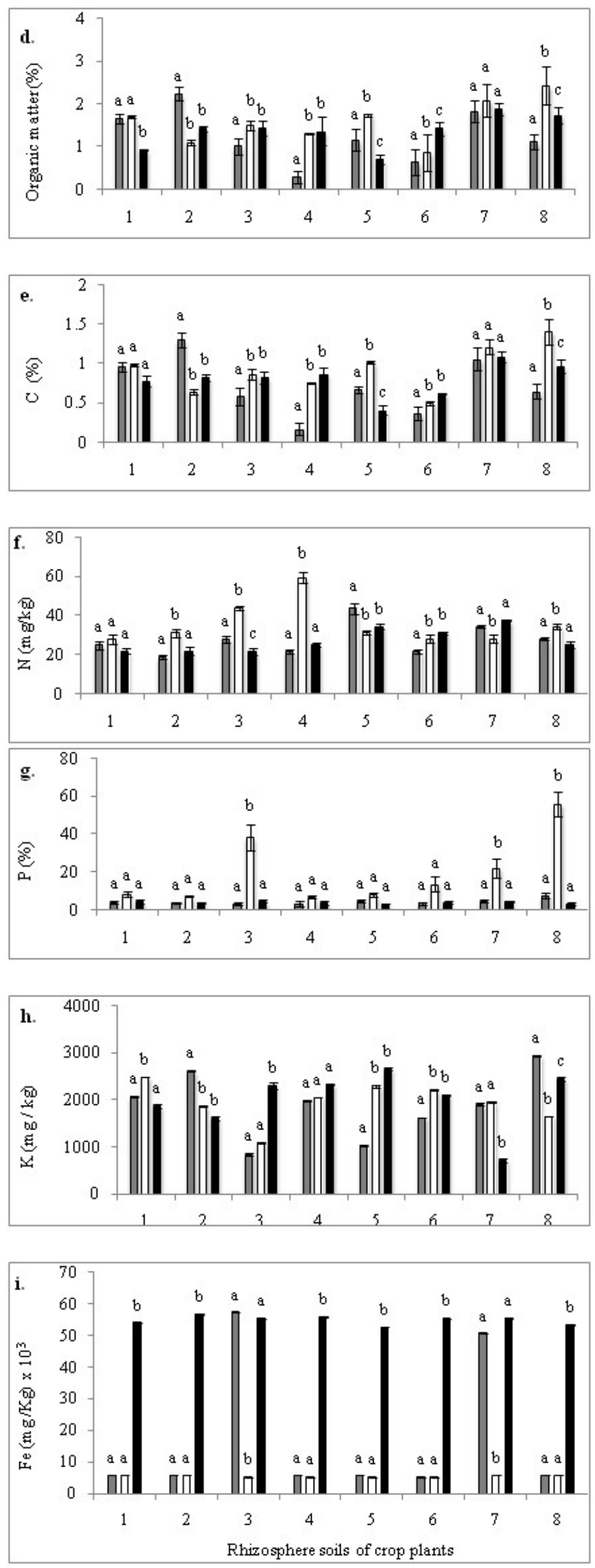

Figure 2: Seasonal variations in physicochemical parameters a) rhizosphere soil temperature, b) $\mathrm{pH}, \mathrm{c}$ )
Moisture, d) Organic matter, e) C, f) N, g) P, h) K and i) Fe content of rhizosphere soils of eight crop plants (1. Glycine max, 2. Saccharum officinarum, 3. Zea mays, 4. Cajanas cajan, 5. Gossypium arboreum, 6. Triticum aestivum, 7. Sorghum vulgare, and 8. Cicer arietinum). Figures followed by the non-identical letters shows significant $(P<0.05)$ difference among three seasons (Tukey's test). Error bars indicates standard error.

arboreum L. where it was slightly decreased $(6.46 \pm$ $0.6)$. The moisture content was more in winter and it was statistically significant $(P<0.05)$. The maximum amount of organic matter and $\mathrm{C}$ was observed in $C$. arietinum L. collected during monsoon. In this season $\mathrm{N}$ content was found to be elevated in $C$. cajan (L.) Millsp.. There is no significant difference in the case of P content of soil except $Z$. mays, S. vulgare and $C$. arietinum where it was elevated in monsoon. The $\mathrm{K}$ content of soil was more in S. officinarum $(2613 \pm 10$ $\mathrm{mg} / \mathrm{kg})$ and $C$. arietinum $(2936 \pm 11 \mathrm{mg} / \mathrm{kg})$ collected during winter. The high amount of $\mathrm{Fe}$ was observed in all the soil samples during summer as compared to other seasons.

\section{B. AM fungal root infection}

The percentage of root colonized by AM fungi varied with the different crop plants and seasons (Fig. 3a). The colonization rates were more in all crop plants during monsoon season except $G$. arboreum (74 \pm $7.36 \%$ in winter). The highest root colonization was observed in $Z$. mays $(97.03 \pm 2.59 \%)$ followed by $S$. vulgare Pers. $(90 \pm 1.8 \%)$, C. cajan $(81.82 \pm 1.28 \%)$, G. $\max (75 \pm 3.3 \%)$, S. officinarum $(70.12 \pm 1.63 \%)$, G. arboreum $(65.4 \pm 5.39 \%)$, T. aestivum $(60 \pm 2.9$ $\%)$, and $C$. arietinum (45.69 $\pm 3.42 \%)$ where significant differences were found among the seasons. AM root colonization in the form of arbuscule, vesicle, hyphae and occasionally intraradical spores were observed.

\section{AM fungal spore density}

The density of AM fungal spores (expressed as per 50 g dry soil) varied with host plants and season (Fig. $3 b)$. The high spore density of AM fungi was observed in $Z$. mays $(1377 \pm 65.1)$, followed by $G$. arboreum $(1359 \pm 4.7), G$. $\max (1250 \pm 63.2), C$. cajan $(887 \pm 27), S$. vulgare $(472 \pm 31.4)$, and $T$. aestivum $(305 \pm 6.3)$ during winter season. However in monsoon, it was more in the rhizosphere of $C$. arietinum. 


\section{GRSP content}

The two fractions of GRSP were determined in the rhizopspheric soil samples of various crop plants collected during three different seasons (Fig 3c \& 3d). The results revealed that EE-GRSP ranged between 0.28 and $0.35 \mathrm{mg} / \mathrm{g}$ during winter, 0.21 and $0.33 \mathrm{mg} / \mathrm{g}$ during monsoon, and 0.27 and $0.39 \mathrm{mg} / \mathrm{g}$ during summer season. It is also apparent that no significant differences were observed among seasons in G. $\max$, S. officinarum, Z. mays and T. aestivum. The average T-GRSP was found more $(44.4 \pm 3.38 \mathrm{mg} / \mathrm{g})$ in summer. Moreover, high amount of EE-GRSP was estimated in C. arietinum during summer
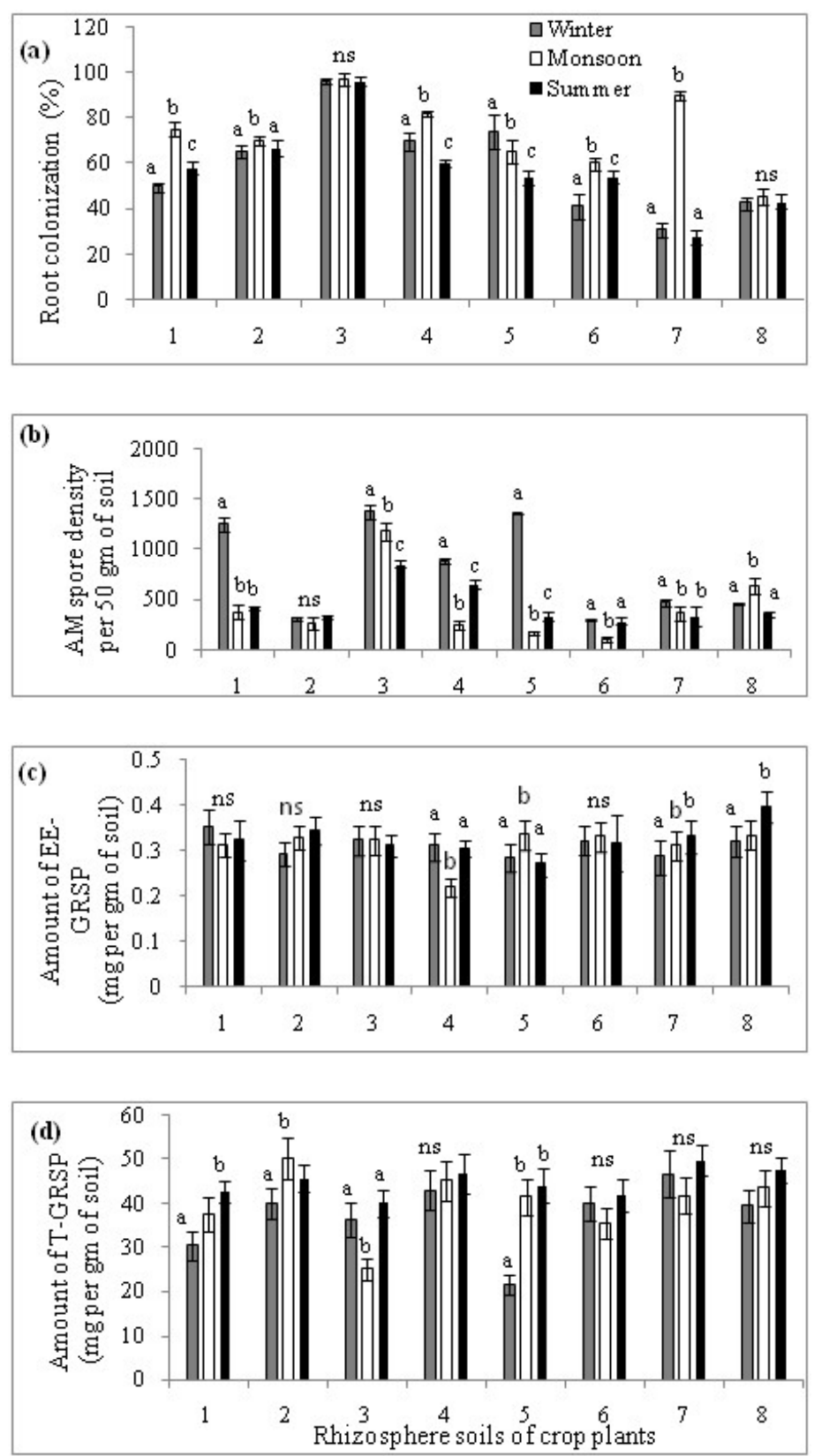

Figure 3: Seasonal variations in : a) root colonization by AM fungi; b) AM spore density per $50 \mathrm{gm}$ of rhizospheric soils; c) Easily extractable glomalin (EEGRSP); and d) Total glomalin (T-GRSP) in rhizospheric soils of eight crop plants (1. Glycine max, 2. Saccharum officinarum, 3. Zea mays, 4. Cajanas cajan, 5. Gossypium arboreum, 6. Triticum aestivum, 7. Sorghum vulgare, and 8. Cicer arietinum). Figures followed by the non-identical letters are significantly $(P<0.05)$ different and ns indicates non-significant difference among three seasons (Tukey's test). Error bars indicates standard error and ns indicates the non-significant differences among seasons.

(Fig. 3c). However the highest amount of T-GRSP $(50.2 \pm 4.63 \mathrm{mg} / \mathrm{g})$ was recorded in $S$. officinarum in monsoon (Fig. 3d).

\section{E. Correlation analysis}

Table 1 shows the Pearson correlation coefficient between soil parameters, AM fungal status and glomalin. T-GRSP content was negatively correlated with AM fungal infection $(P<0.05)$, spore density and moisture content of soil $(P<0.01)$. It also showed positive correlation with rhizospheric temperature, $\mathrm{K}$ and Fe content of soil $(P<0.05)$. EE-GRSP exhibited negative correlation with amount of $\mathrm{N}(P<0.05)$. AMF spore density was positively correlated with moisture $(P<0.05)$ and it was negative with $\mathrm{K}(P<$ $0.01)$. AMF root colonization also showed negative correlation with $\mathrm{K}(P<0.05)$. Positive correlation has been observed between temperature and $\mathrm{Fe}(P<$ $0.01)$; $\mathrm{P}$ and organic matter and $\mathrm{C}(P<0.05)$. Moreover, strong positive correlation was found between organic matter and $\mathrm{C}(\mathrm{r}=0.97, P<0.01)$. Overall, this data showed that T-GRSP is linked with temperature, moisture, $\mathrm{P}, \mathrm{K}, \mathrm{Fe}, \mathrm{C}$, organic matter, $\mathrm{AM}$ root colonization and spore density.

\section{F. Regression analysis}

The variables that showed significant correlation were further analysed by linear regression model for three different seasons separately (Table 2). The negative association was observed between $\mathrm{K}$ and spore density, and $\mathrm{N}$ and EE-GRSP during monsoon. TGRSP exhibited positive relationship with temperature. It was negatively related with soil moisture and spore density in winter. In contrast, root colonization was negatively associated with T-GRSP during summer season. These relationships were statistically significant $(P<0.05)$.

\section{G. PCA analysis}

The method of PCA is the special case of the more general method of Factor analysis. The Eigen values 
International Journal of Trend in Scientific Research and Development (IJTSRD) ISSN: 2456-6470

of the first, second and third components were 3.72, 2.55 and 1.77 respectively. The cumulative percentage variance of this data showed that first three components explain $61.88 \%$ of the variability. The resulting ordination diagram (Fig. 4) indicates that TGRSP was influenced by rhizospheric temperature and $\mathrm{Fe}$ content of soil during summer season. In monsoon season, soil parameters such as moisture, $\mathrm{pH}, \mathrm{C}$, organic matter and $\mathrm{C}$ has high influence on EE-GRSP. However, AM spore density and root colonization were positively influenced by $\mathrm{N}$ content of soil during winter season.

Table 1: Correlation matrix of root colonization by AM fungi (RC), AM spore density (SD), EE-GRSP, TGRSP and soil edaphic factors. Pearson correlation on the means $(\mathrm{n}=24)$ are shown (OM-organic matter).

\begin{tabular}{|l|l|l|l|l|l|l|l|l|l|l|l|l|}
\hline Factors & \multicolumn{1}{|c|}{$\mathrm{T}$} & $\mathrm{pH}$ & $\begin{array}{c}\text { Moistu } \\
\mathrm{re}\end{array}$ & $\mathrm{OM}$ & $\mathrm{C}$ & $\mathrm{N}$ & $\mathrm{P}$ & $\mathrm{K}$ & $\mathrm{Fe}$ & $\mathrm{RC}$ & $\mathrm{SD}$ & $\begin{array}{c}\text { EE- } \\
\text { GRSP }\end{array}$ \\
\hline $\mathrm{pH}$ & -0.37 & & & & & & & & & & & \\
\hline Moisture & $-0.57^{* *}$ & 0.11 & & & & & & & & & & \\
\hline $\mathrm{OM}$ & -0.21 & 0.22 & -0.04 & & & & & & & & & \\
\hline $\mathrm{C}$ & -0.19 & 0.18 & -0.08 & $0.97^{* *}$ & & & & & & & & \\
\hline $\mathrm{N}$ & -0.04 & -0.10 & -0.03 & 0.08 & 0.05 & & & & & & & \\
\hline $\mathrm{P}$ & $-0.55^{* *}$ & -0.04 & 0.21 & $0.44^{*}$ & $0.44^{*}$ & 0.27 & & & & & & \\
\hline $\mathrm{K}$ & 0.39 & -0.18 & -0.37 & 0.15 & 0.14 & -0.22 & -0.30 & & & & & \\
\hline $\mathrm{Fe}$ & $0.62^{* * *}$ & -0.15 & $-0.50^{*}$ & -0.04 & -0.03 & -0.23 & -0.37 & 0.07 & & & & \\
\hline $\mathrm{RC}$ & -0.11 & 0.33 & 0.05 & -0.10 & -0.09 & 0.14 & 0.14 & $-0.45^{*}$ & -0.17 & & & \\
\hline $\mathrm{SD}$ & -0.23 & 0.07 & $0.43^{*}$ & -0.11 & -0.10 & 0.08 & 0.12 & $-0.61^{* *}$ & -0.0 & 0.39 & & \\
\hline EEGRSP & -0.09 & 0.32 & 0.13 & 0.17 & 0.16 & $-0.56^{* *}$ & 0.11 & 0.01 & 0.15 & -0.25 & 0.04 & \\
\hline T-GRSP & $0.45^{*}$ & -0.16 & $-0.68^{* *}$ & 0.09 & 0.10 & -0.17 & -0.19 & $0.48^{*}$ & $0.42^{*}$ & $-0.41^{*}$ & $-0.67^{* *}$ & 0.04 \\
\hline
\end{tabular}

Correlation is significant at $0.01\left({ }^{* *}\right)$ and $0.05\left({ }^{*}\right)$ level of probability.

Table 2: Regression analysis among edaphic factors, mycorrhizal status and GRSP content of rhizospheric soil samples collected during three different seasons

\begin{tabular}{|c|c|c|c|}
\hline Relation between & \multicolumn{3}{|c|}{ Regression algorithms (equation of regression line, $R^{2}$ and $P$ values) } \\
\hline & Winter & Monsoon & Summer \\
\hline $\begin{array}{l}\text { Moisture and AM } \\
\text { spore density }\end{array}$ & $\begin{array}{l}\mathrm{y}=33.76 \mathrm{x}-128.2 \\
\mathrm{R}^{2}=0.278, P=0.179\end{array}$ & $\begin{array}{l}\mathrm{y}=4.993 \mathrm{x}+317.04 \\
\mathrm{R}^{2}=0.017, P=0.759\end{array}$ & $\begin{array}{l}\mathrm{y}=-19.45 \mathrm{x}+668.9 \\
\mathrm{R}^{2}=0.078, P=0.504\end{array}$ \\
\hline $\begin{array}{l}\mathrm{K} \text { and } \mathrm{AM} \text { spore } \\
\text { density }\end{array}$ & $\begin{array}{l}\mathrm{y}=-0.443 \mathrm{x}+1635 \\
\mathrm{R}^{2}=0.448, P=0.07\end{array}$ & $\begin{array}{l}\mathrm{y}=-0.686 \mathrm{x}+1758 \\
\mathrm{R}^{2}=0.75, P=0.005\end{array}$ & $\begin{array}{l}\mathrm{y}=0.095 \mathrm{x}+257.7 \\
\mathrm{R}^{2}=0.086, P=0.48\end{array}$ \\
\hline $\mathrm{N}$ and EE-GRSP & $\begin{array}{l}\mathrm{y}=-0.001 \mathrm{x}+0.347 \\
\mathrm{R}^{2}=0.196, P=0.272\end{array}$ & $\begin{array}{l}\mathrm{y}=-0.003 \mathrm{x}+0.415 \\
\mathrm{R}^{2}=0.69, P=0.011^{*}\end{array}$ & $\begin{array}{l}\mathrm{y}=0.002 \mathrm{x}+0.374 \\
\mathrm{R}^{2}=0.098, P=0.451\end{array}$ \\
\hline $\begin{array}{l}\text { Temperature and } \mathrm{T} \text { - } \\
\text { GRSP }\end{array}$ & $\begin{array}{l}\mathrm{y}=-1.523 \mathrm{x}+73.58 \\
\mathrm{R}^{2}=0.274, P=0.183\end{array}$ & $\begin{array}{l}\mathrm{y}=1.02 \mathrm{x}+16.19 \\
\mathrm{R}^{2}=0.49, P=0.032 *\end{array}$ & $\begin{array}{l}\mathrm{y}=-0.07 \mathrm{x}+47.16 \\
\mathrm{R}^{2}=0.009, P=0.825\end{array}$ \\
\hline $\begin{array}{l}\text { Moisture and T- } \\
\text { GRSP }\end{array}$ & $\begin{array}{l}\mathrm{y}=-0.79 \mathrm{x}+58.99 \\
\mathrm{R}^{2}=0.551, P=0.035^{*}\end{array}$ & $\begin{array}{l}\mathrm{y}=-0.39 \mathrm{x}+48.03 \\
\mathrm{R}^{2}=0.219, P=0.242\end{array}$ & $\begin{array}{l}\mathrm{y}=-0.294 \mathrm{x}+48.18 \\
\mathrm{R}^{2}=0.068, P=0.534\end{array}$ \\
\hline $\mathrm{K}$ and T-GRSP & $\begin{array}{l}\mathrm{y}=0.005 \mathrm{x}+27.98 \\
\mathrm{R}^{2}=0.2, P=0.267\end{array}$ & $\begin{array}{l}\mathrm{y}=0.007 \mathrm{x}+26.16 \\
\mathrm{R}^{2}=0.171, P=0.308\end{array}$ & $\begin{array}{l}\mathrm{y}=-0.003 \mathrm{x}+50.09 \\
\mathrm{R}^{2}=0.246, P=0.211\end{array}$ \\
\hline Fe and T-GRSP & $\begin{array}{l}\mathrm{y}=0.00 \mathrm{x}+35.25 \\
\mathrm{R}^{2}=0.096, P=0.454\end{array}$ & $\begin{array}{l}\mathrm{y}=0.01 \mathrm{x}-14.53 \\
\mathrm{R}^{2}=0.209, P=0.255\end{array}$ & $\begin{array}{l}\mathrm{y}=0.00 \mathrm{x}+35.56 \\
\mathrm{R}^{2}=0.005, P=0.866\end{array}$ \\
\hline $\begin{array}{l}\text { Root colonization } \\
\text { and T-GRSP }\end{array}$ & $\begin{array}{l}\mathrm{y}=-0.148 \mathrm{x}+45.88 \\
\mathrm{R}^{2}=0.165, P=0.319\end{array}$ & $\begin{array}{l}\mathrm{y}=-0.191 \mathrm{x}+53.99 \\
\mathrm{R}^{2}=0.177, P=0.299\end{array}$ & $\begin{array}{l}\mathrm{y}=-0.128 \mathrm{x}+52.2 \\
\mathrm{R}^{2}=0.601, P=0.024 *\end{array}$ \\
\hline $\begin{array}{l}\text { AM spore density } \\
\text { and T-GRSP }\end{array}$ & $\begin{array}{l}\mathrm{y}=-0.012 \mathrm{x}+46.64 \\
\mathrm{R}^{2}=0.499, P=0.05^{*}\end{array}$ & $\begin{array}{l}\mathrm{y}=-0.014 \mathrm{x}+46.03 \\
\mathrm{R}^{2}=0.432, P=0.076\end{array}$ & $\begin{array}{l}\mathrm{y}=-0.007 \mathrm{x}+47.81 \\
\mathrm{R}^{2}=0.165, P=0.317\end{array}$ \\
\hline
\end{tabular}

* indicates significance at $P</=0.05$. 


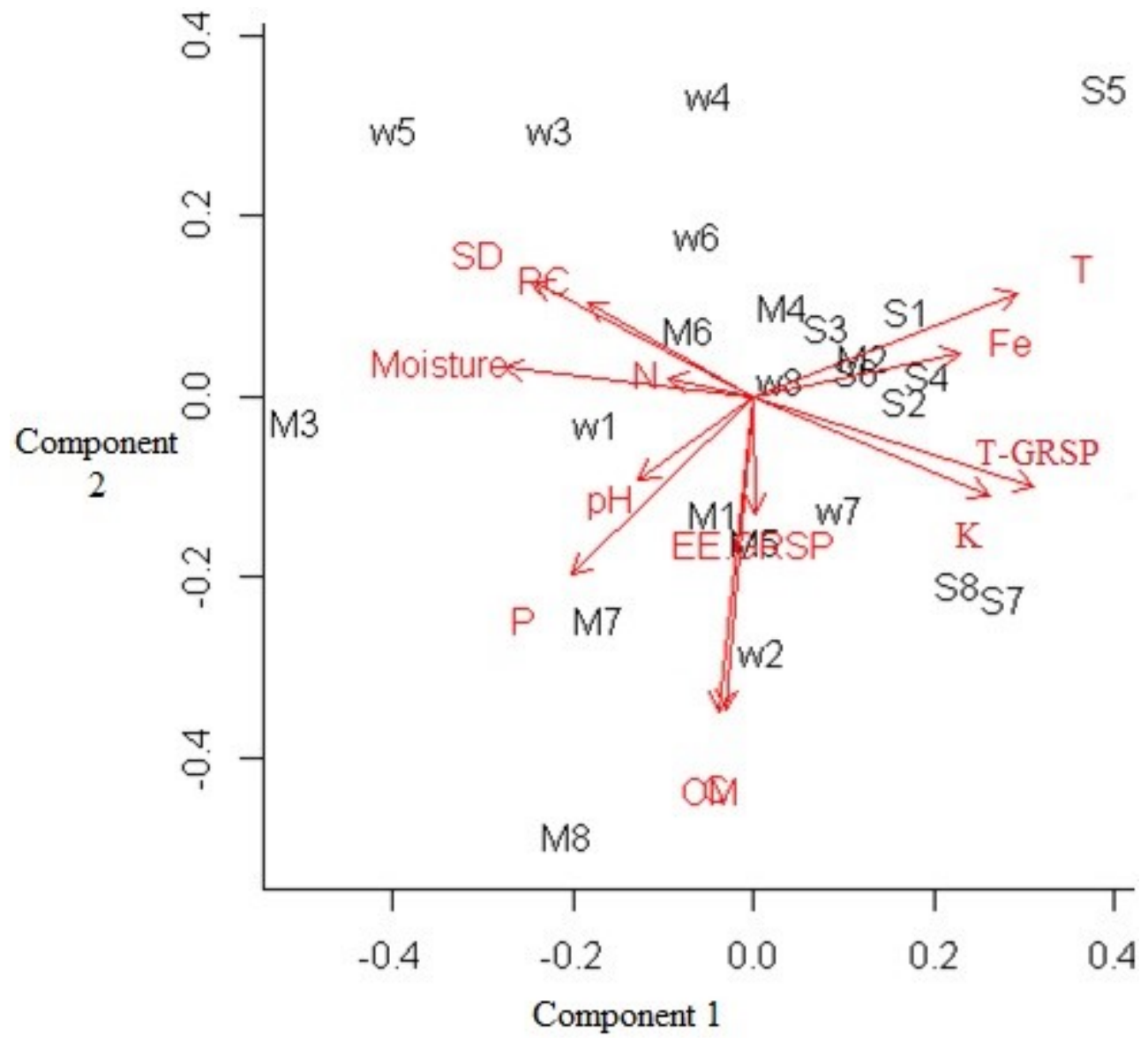

Figure 4: Diagram of a PCA of soil edaphic factors with AM root colonization (RC), AM fungal spore density (SD) and GRSP in the rhizosphere of eight crop plants (1. Glycine max, 2. Saccharum officinarum, 3. Zea mays, 4. Cajanas cajan, 5. Gossypium arboreum, 6. Triticum aestivum, 7. Sorghum vulgare, and 8. Cicer arietinum) collected during three different seasons (w1-w8: winter; M1-M8: monsoon and S1-S8: summer).

\section{IV.DISCUSSION}

\section{A. Seasonal changes in soil properties}

The data showed that seasonal variation in soil edaphic factors had positive influence on the the crop plants studied. The soil parameters such as $\mathrm{pH}$, organic matter, $\mathrm{C}, \mathrm{N}$ and $\mathrm{P}$ were found to be elevated in monsoon season. It may be due to the fact that during this season, the plants experience good rainfall, average temperatures besides receiving nutrients in required proportions (Hindumathi and Reddy, 2011). On the other hand, Fe content of soil was found more in summer. Delbari and Kulkarni (2011) also reported the high amount of $\mathrm{Fe}$ in agricultural soils during summer.

\section{B. Seasonal changes in AMF status of crop plants}

The crop plants G. max, S. officinarum, Z. mays, $S$. vulgare, $C$. cajan and $T$. aestivum showed higher AMF root colonization ( $>70 \%$ ) in monsoon season $(P<0.05)$. Similar results were obtained in previous study (Kumar et al., 2010). The maximum root colonization in Withania somnifera was observed during late rainy season. The higher root colonization may be attributed to the capacity of AM fungi to obtain higher profits from growing plants at abundant rainfall. On the other hand, the high density of AMF spores was estimated in G. $\max , Z$. mays, C. cajan, $G$. arboreum and $S$. vulgare (472-1377 spores per $50 \mathrm{~g}$ soil) during winter $(P<0.05)$. The maximum sporulation in this season could be correlated with the fact that during this period most photosynthate is allocated to roots and rhizomes, which helps fungal symbionts to produce more spores (Gemma and Koske, 1988). It is affirmed from the results that AM sporulation and root colonization has seasonal dynamics, which is directly or indirectly influenced by different intervals of year. The seasonal changes and different range of spore density and root colonization are due to a wide range of hosts. de Oliveira and de Oliveira (2005) have reported that maximum sporulation and colonization of AM fungi was registered in rainy season in case of Theobroma grandiflorum Schum. and Paullinia cupana Mart. From these reports it can be postulate that monsoon 
and winter seasons are favourable for root infection and sporulation respectively for crop plants studied.

\section{Seasonal variation in glomalin content of rhizosphere soils of crop plants}

Previous studies have considered seasonality of GRSP in grassland and desert ecosystems (Lutgen et al., 2003; Clark et al., 2009). In the present study, we reported seasonality of GRSP in agroecosystem first time. Statistically significant seasonal variation in TGRSP was observed. The average T-GRSP was found to be more $(44.4 \pm 3.38 \mathrm{mg} / \mathrm{g})$ during summer. These results correspond to the higher amount of T-GRSP in rhizosphere of Artemisia ordosica Krasch. during summer in Mu Us Sandland, China (He et al., 2010). The high amount of T-GRSP in summer may be due to rise in rhizosphere temperature in this season. This is also supported by finding of Gadkar and Rillig (2006) where it was reported that glomalin is putative homolog of heat shock protein 60 . However, no significant seasonal changes were observed in case of EE-GRSP. Rillig et al. (2003) suggested that a portion of glomalin is labile while a size- able proportion of this pool would not be expected to show any measurable seasonal change owing to its low turnover.

Since leguminous plant produce large number of AMF spores (Carrhino et al., 2002) and the majority $(>80 \%)$ of glomalin produced by AMF was contained in hyphae and spores (Driver et al., 2005), it is expected that AMF associated with legumes produce higher amount of fresh fraction, EE-GRSP. This is affirmed by our results that the high amount of EEGRSP was estimated in C. arietinum $(0.4 \mathrm{mg} / \mathrm{g})$ as compared to other crop plants. These reports further corroborate that higher EE-GRSP content in $C$. arietinum might be related to higher mycorrhizal infection and spore density favoured by flavonoids of legume (Howeler et al., 1987; D'arcy-Lameta, 1988). On the other hand, the highest amount of T-GRSP $(50.2 \pm 4.63 \mathrm{mg} / \mathrm{g})$ was recorded in S. officinarum. This may be due to the fact that monocots and other crop plants produce enormous root biomass in short period of time and hence they are acknowledged in mass production of AMF inoculums (Douds et al. 2005; Chaurasia \& Khare 2005; Bagyaraj \& Manjunath 1980). Moreover, Lutgen et al (2003) speculated that roots themselves contain glomalin (in intraradical fungal structures) and that this is reflected in soil extractions.

\section{Relationship between edaphic factors, AMF and glomalin}

The data of correlation, regression and PCA analyses showed significant correlation between soil edaphoclimatic factors, AMF and GRSP. AMF root colonization and spore density was negatively influenced by $\mathrm{K}$ content of soil. This is attributed to the fact that AMF play major role in nutrient deficient soils such as N, P and K (Chen and Zhao 2009). When plants have high nutrient availability, a negative response and low AMF spore population should be expected (Dhillon and Zak, 1993). On the other hand, positive correlation existed between AMF spore density and moisture content of soil. Kumar et al (2010) also reported the positive correlation between soil moisture and spore number in medicinal plants. This may be associated with the development of the plant root system due to increase in the water content of soil and simultaneous increase in nutrient absorption and liberation of root exudates stimulating mycorrhizal infection and subsequent sporulation ( $\mathrm{He}$ et al., 2002).

In this study, GRSP content was decreased with increase in AMF root colonization $(P=0.024)$ and spore density $(P=0.05)$. This may be due to the fact that glomalin concentrations increased in soil with hyphal decomposition, and in the absence of new hyphal glomalin production (Steinberg and Rillig, 2003). The increase in glomalin could be reflective of glomalin liberated from decomposing hyphal walls. In addition, hyphal residence time (from days to months) is less than GRSP residence time (6-42 years) (Langley and Hungate 2003; Staddon et al. 2003; Rillig et al. 2001). The moisture $(P=0.035)$ and $\mathrm{N}$ content $(P=0.011)$ had negative influence on glomalin concentration. However, rhizosphere temperature, K, Fe had positive influence on GRSP. These findings corroborate the speculations by other studies (Rillig and Steinberg, 2002; Driver et al., 2005) that glomalin may act as a protective agent for AMF as a stress-induced protein. The metallic ions (ferric ions) in GRSP seem to have a role in protecting and stabilizing this protein (Nichols and Wright 2005). Rillig and Steinberg (2002) demonstrated that unfavourable growing conditions may enhance glomalin production by AMF. In addition, the amino acid sequences of glomalin are related to heat shock protein (hsp60) which are proteins produced by eukaryotic and prokaryotic cells when under environmental related stress conditions such as increased temperatures, $\mathrm{pH}$ change and starvation 
(Gadkar and Rillig, 2006; Purin and Rillig, 2007). Thus, glomalin can be implicated as an indicator soil protein for evaluating soil quality under abiotic stress conditions.

\section{E. Conclusions}

The present study reveals distinct seasonal changes of glomalin and AMF associated with Glycine max (L.) Merr., Saccharum officinarum L., Zea mays L., Cajanas cajan (L.) Millsp., Gossypium arboreum L., Triticum aestivum L., Sorghum vulgare Pers. and Cicer arietinum L. which are commonly cultivated in Nanded district. It is evident from the data that the response of $\mathrm{AMF}$ varies with different crop plants and hence it reflects the variation in glomalin. The winter and monsoon seasons favours the growth of AMF while summer is suitable for glomalin production. Moreover, glomalin was negatively influenced by AMF and soil moisture; and positively influenced by temperature, $\mathrm{Fe}$ and $\mathrm{K}$ content of soil. Therefore, it can be inferred that glomalin is produced in environmental stress and can be implicated for evaluating soil quality in agricultural fields. Future research would be beneficial for a better understanding of seasonal variations in glomalin concentrations and diversity of AMF in agroecosystem.

\section{ACKNOWLEDGEMENTS}

Authors are thankful to Dr. S. K. G. Krishnamacharyulu Professor \& Co-ordinator Geoinformatics, School of Earth Sciences, Swami Ramanand Teerth Marathwada University, Nanded, Maharashtra, India for providing SPSS 13.0 software.

\section{REFERENCES}

1. Abbott, L.K. and Robson A.D. 1991. Factors influencing the occurrence of Vesicular Arbuscular Mycorrhiza. Agriculture, Ecosystem, Environment 35: 121-150.

2. Al-Karaki, G.N., Hammad, R. and Rusan, M. 2001. Response of two tomato cultivars differing in salt tolerance to inoculation with mycorrhizal fungi under salt stress. Mycorrhiza 11: 43-47.

3. Anderson, J.M. and Ingram J.S.I. 1993. Tropical Soil Biology and Fertility. A handbook of methods. CAB International. Wallingford, England.

4. Anderson, R. C., Liberta, A. E. and Dickman, L. A. 1984. Interaction of vascular plants and vesicular-arbuscular mycorrhizal fungi across a soil moisture-nutrient gradient. Oecologia 64, 111-117.

5. Augé, R.M., Sylvia, D.M. and Park., S. 2004. Partitioning mycorrhizal influence on water relations of Phaseolus vulgaris into soil and plant components. Canadian Journal of Botany 82: 503-514.

6. Bagyaraj, D.J. and Manjunath., A. 1980. Selection of suitable host for mass production of VA mycorrhizal inoculum. Plant Soil 55: 495-49.

7. Ball-Coelho, Salcedo, I.H., Tiessen, H. and Stewart J.W. 1993. Short and Long-term phosphorus dynamics in fertilized Ultisol under sugarcane. Soil Science Society of America Journal 1027-1033.

8. Carrenho, R., Sandra, F.B., Trufem and Bononi V.R. 2002. Effects of using different host plants on the detected biodiversity of arbuscular mycorrhizal fungi from an agroecosystem. Revista Brasileira de Botanica 25(01): 93-101.

9. Chaurasia, B. and Khare., P.K. 2005. Hordeum vulgare: a suitable host for mass production of arbuscular mycorrhizal fungi from natural soil. Applied Ecology and Environmental Research 4(1): 45-53.

10. Chen, X.H. and Zhao, B. 2009. Arbuscular mycorrhizal fungi mediated uptake of nutrient elements by Chinese milk vetch (Astragalus sinicus L.) grown in lanthanum spiked soil. Biology and Fertility of Soils 45: 675-678.

11. Clark, N.M., Rillig, M.C. and Nowak, R.S. 2009. Arbuscular mycorrhizal fungal abundance in the Mojave Desert: Seasonal dynamics and impacts of elevated $\mathrm{CO}_{2}$. Journal of Arid Environments 73: 834-843.

12. D'Arcy-Lameta, A. 1988. Study of soybean and lentil root exudates. II. Identification of some polyphenolic compounds, related with plant physiology. Plant and Soil 92: 113-123.

13. Davies, F.T., Olalde-Portugal, V., AguileraGomez, L., Alvarado, M.J., Ferrera-Cerrato, R.C. and Boutton, T.W. 2002. Alleviation of drought stress of Chile ancho pepper (Capsicum annuum L. cv. San Luis) with arbuscular mycorrhiza indigenous to Mexico. Scientia Horticulturae 92: 347-359.

14. De Oliveira, A.N. and de Oliveira, L.A. 2005. Seasonal dynamics of arbuscular mycorrhizal 
fungi in plants of Theobroma grandiflorum Schum. and Paullinia cupana Mart. of an agroforestry system in Central Amazonia, Amazonas state, Brazil. Brazilian Journal of Microbiology 36: 262-270.

15. Delbari, A.S. and Kulkarni, D.K. 2011. Seasonal variations in heavy concentrations in agriculture soils in Teheran-Iran. Bioscience Discovery 2(3): 333-340.

16. Dhillon, S.S. and Zak, J.C. 1993. Microbial dynamics in arid ecosystems-desertification and the potential role of mycorrhizas. Revista Chilena De Historia Natural 66: 253-270.

17. Douds, Jr. D.D., Nagahashi, G., Pfeffer, P.E., Kayser, W.M. and Reider, C. 2005. On-farm production and utilization of arbuscular mycorrhizal fungus inoculum. Canadian Journal of Plant Science 85(1): 15-21.

18. Driver, J.D., Holben, W.E. and Rillig, M.C. 2005. Characterization of glomalin as a hyphal wall component of arbuscular mycorrhizal fungi. Soil Biology and Biochemistry 37: 101-106.

19. Gadkar, V. and Rillig M.C. 2006. The arbuscular mycorrhizal fungal protein glomalin is a putative homolog of heat shock protein 60. FEMS Microbiology Letters 263: 93-101.

20. Gay, P. E., Grubb, P. J. and Hudson, H. J. 1982. Seasonal changes in the concentrations of nitrogen, phosphorous, and potassium, and in the density of mycorrhiza, in bienniel and matrix forming perennial species of closed chalkland turf. Journal of Ecology 70: 571-593.

21. Gemma, J.N. and Koske, R.E. 1988. Seasonal variation in spore abundance and dormancy of Gigaspora gigantean and in mycorrhizal inoculum potential of dune soil. Mycologia 80: 211-216.

22. Gerdmann, J.W. and Nicolson, T.H. 1963. Spores of mycorrhizal Endogone species extracted from soil by wet sieving and decanting. Transactions of the British Mycological Society 46: 235-244.

23. Graham, J.H. 2001. What do root pathogens see in mycorrhizas? New Phytologist 149: 357-359.

24. He, X., Mouatov, S. and Steinberger, Y. 2002. Temporal and special dynamics of vesicular arbuscular mycorrhizal fungi under the canopy of Zygophyllum dumosum Boiss. in the Negev Desert. Journal of Arid Environment 52: 379-387.
25. He, X., Li, Y. and Zhao, L. 2010. Dynamics of arbuscular mycorrhizal fungi and glomalin in the rhizosphere of Artemisia ordosica Krasch. In $\mathrm{Mu}$ Us sandland, China. Soil Biology and Biochemistry 42: 1313-1319.

26. Hindumathi, A. and Reddy, B.N. 2011. Occurrence and distribution of arbuscular mycorrhizal fungi and microbial flora in the rhizosphere soils of mungbean and soybean from Adilabad, Nizamabad and Karimnagar districts of Andhra Pradesh state, India. Advances in Bioscience and Biotechnology 2: 275-286.

27. Hodge, A., Campbell, C.D. and Fitter, A.H. 2001. An arbuscular mycorrhizal fungus accelerates decomposition and acquires nitrogen directly from organic material. Nature 413: 297-299.

28. Howeler, R.H., Sieverding, E. and Saif, S.R. 1987. Practical aspects of mycorrhizal technology in some tropical crops and pastures. Plant and Soil 100: 249-283.

29. Jastrow, J. D. and Miller, R. M. 1997. Soil aggregate stabilization and carbon sequestration: feedbacks through organomineral associations $\mathrm{p}$. 207-222. In: Lal, R., Kimble, J. M., Follett, R. F. and Stewart, B. A. edited. Soil Processes and the Carbon Cycle. CRC Press, Boca Raton, LA.

30. Johnson, N. C., Zak, D. R., Tilman, D. and Pfleger, F. L. 1991. Dynamics of vesiculararbuscular mycorrhizae during old field succession. Oecologia 86: 349-358.

31. Kumar, A., Mangla, C., Aggarwal, A. and Parkash, V. 2010. Arbuscular mycorrhizal fungal dynamics in the rhizospheric soil of five medicinal plant species. Middle-East Journal of Scientific Research 6 (3): 281-288.

32. Langley, J.A. and Hungate, B.A. 2003. Mycorrhizal controls on belowground litter quality. Ecology 84: 2302-2312.

33. Lutgen, E.R., Deborah, M.C., Graham, J. and Rillig, M.C. 2003. Seasonality of arbuscular mycorrhizal hyphae and glomalin in a western Montana grassland. Plant and Soil 257: 71-83.

34. Miller, R.M. and Jastrow, J.D. 2000. Mycorrhizal fungi influence soil structure. p. 3-18. In: Kapulnik, Y., Douds, D.D. edited. Arbuscular Mycorrhizas: Molecular Biology and Physiology. Kluwer Academic, Dordrecht. 
35. Mullen, R. B. and Schmidt, S. K. 1993. Mycorrhizal infection, phosphorous uptake, and phenology in Ranunculus adoneus: implications for the functioning of mycorrhizae in alpine systems. Oecologia 94: 229-234.

36. Nichols, K.A. and Wright, S.F. 2005. Comparison of glomalin and humic acid in eight native US soils. Soil Science 170: 985-997.

37. Nicolson, T.H. 1955. The mycotrophic habit in grass. p. 227-286. Thesis paper, Nottingham, UK: University of Nottingham.

38. Phillips, J.M. and Hayman, D.S. 1970. Improved proceduring for clearing roots and staining parasitic and vesicular-arbuscular mycorrhizal fungi for rapid assessment of infection. Transaction of the British Mycological Society 54: 53-63.

39. Purin, S. and Rillig M.C. 2007. The arbuscular mycorrhizal fungal protein glomalin: Limitations, progress, and a new hypothesis for its function. Pedobiologia 51: 123-130.

40. Rillig, M.C. and Steinberg, P.D. 2002. Glomalin production by an arbuscular mycorrhizal fungus: a mechanism of habitat modification. Soil Biology and Biochemistry 34: 1371-1374.

41. Rillig, M.C., Wright, S.F., Nichols, K.A., Schmidt, W.F. and Torn, M.S. 2001. Large contribution of arbuscular mycorrhizal fungi to soil carbon pools in tropical forest soils. Plant Soil 233: $167-177$.

42. Rillig, M.C., Ramsey, P.W., Morris, S. and Paul, E.A. 2003. Glomalin, an arbuscular-mycorrhizal fungal soil protein, responds to land-use change. Plant Soil 253: 293-299.

43. Sanders, F.E. and Fitter, A.H. 1992. The ecology and functioning of vesicular-arbuscular mycorrhizas in co-existing grassland species. I.
Seasonal patterns of mycorrhizal occurrence and morphology. New Phytologist 120: 517-524.

44. Shahapurkar, O. and Gajre N. 2011. Spatiotemporal analysis of general landuse pattern in Nanded district - a geographical review. Interlink Research Analysis 1 (4): 75-80.

45. Sieverding, E. 1991. Vesicular-arbuscular mycorrhiza management in tropical ecosystem. GTZ, Germany.

46. Smith, S.E. and Read, D.J. 2008. Mycorrhizal Symbiosis. p. 787.Academic Press, London. Staddon, P.L., Bronk-Ramsey, C., Ostle, N., Ineson, P. and Fitter, A.H. 2003. Rapid turnover of hyphae of mycorrhizal fungi determined by AMS microanalysis of 14C. Science 300: 11381140 .

47. Steinberg, P.D. and Rillig, M.C. 2003. Differential decomposition of arbuscular mycorrhizal fungal hyphae and glomalin. Soil Biology and Biochemistry 35: 191-194.

48. Subbiah, B.V. and Asija, G.L. 1956. A rapid procedure for the determination of available nitrogen in soils. Current Science 25: 259-260.

49. Trivedy, R.K., Goel, P.K. and Trisal, C.L. 1998. Practical methods in ecology and environmental science. $2^{\text {nd }}$ edition. Enviro Media Publication, Karad, India.

50. Wright, S. F., Franke-Snyder, M., Morton, J. B. and Upadhyaya, J. 1996. Time-course study and partial characterization of a protein on hyphae of arbuscular mycorrhizal fungi during active colonization of roots. Plant Soil 181: 193-203.

51. Wright, S.F. and Upadhyaya, A. 1996. Extraction of an abundant and unusual protein from soil and comparison with hyphal protein of arbuscular mycorrhizal fungi. Soil Science 161: 575-586. 